\title{
Reviewing the Oceanic Niño Index (ONI) to Enhance Societal Readiness for El Niño's Impacts
}

\author{
Michael H. Glantz ${ }^{1}$ Ivan J. Ramirez ${ }^{1,2}$
}

Published online: 18 May 2020

(C) The Author(s) 2020

\begin{abstract}
NOAA's Oceanic Niño Index (ONI) is used to record for historical purposes the occurrence and duration of El Niño episodes, based on the monitoring of sea surface temperatures (SSTs) in the central Pacific Ocean. The ONI is used to identify the onset of an above average SST threshold that persists for several months, encompassing both the beginning and end of an El Niño episode. The first appearance of an anomalous seasonal value of $0.5{ }^{\circ} \mathrm{C}$ suggests with a high probability that an El Niño could emerge, but for heightened warnings, one must wait for several months. In this article, we proposed that the ONI value of $0.7{ }^{\circ} \mathrm{C}$ identifies a tipping point at which the El Niño event becomes locked in, which can provide additional lead time for mitigative actions to be taken by societal decision makers. Our preliminary findings suggest that a first appearance of $0.7^{\circ} \mathrm{C}$ value could serve as a credible marker of El Niño's locked-in phase, which can provide additional credibility to the current $0.5{ }^{\circ} \mathrm{C}$ El Niño onset indicator for at-risk societies to get ready for $\mathrm{El}$ Niño's foreseeable societal and ecological impacts.
\end{abstract}

Keywords Advisory - Disasters · Early warning $\cdot$ El Niño $\cdot$ El Niño Southern Oscillation · ENSO · Hydrometeorological hazards · Oceanic Niño Index $\cdot$ ONI

Michael H. Glantz

mickeyglantz@hotmail.com

1 Consortium for Capacity Building/INSTAAR, University of Colorado, Boulder, CO 80309, USA

2 Department of Health and Behavioral Sciences, University of Colorado Denver, Denver, CO 80204, USA

\section{Introduction to the Oceanic Niño Index (ONI)}

El Niño is the anomalously warm sea surface temperature phase of the ENSO (El Niño Southern Oscillation) quasiperiodic cycle in air-sea interactions in the tropical Pacific that swings through a neutral phase between warm (El Niño) and cold (La Niña) extremes. El Niño recurs at some time between 2 and 7 years, or $41 / 2$ years on average, and can last from 9 to 18 months. From 1950 to 2020, 23 El Niño episodes officially occurred using the ONI threshold criterion.

Each ENSO extreme is associated with its own set of foreseeable regional climate, water, and weather-related anomalies, referred to as "teleconnections," such as droughts, floods, heatwaves, forest and brush fires, and other severe hydrometeorological events (McPhaden et al. 2006). Such anomalies can have adverse impacts on food security, water resources, energy supply, human health, and lives and livelihoods in various countries around the globe (Caviedes 1984; Glantz 2001; Ramírez et al. 2013; Zebiak et al. 2015; McGregor and Ebi 2018; Ubilava and Abdolrahimi 2019). The updated original impacts map by Ropelewski and Halpert (1987) provides regions foreseeably affected by El Niño's impacts (Fig. 1).

National Oceanic and Atmospheric Administration's (NOAA) Climate Prediction Center (CPC) monitors changes in sea surface temperatures (SSTs) in the tropical Pacific Ocean for the purpose of forecasting the onset and tracking the life cycle of El Niño events. One important way it does this is to use its Oceanic Niño Index (ONI), which is based on variations in 3-month running means (3MRMs) of SSTs in a central Pacific region defined as Niño 3.4 (NOAA 2019a, b) (see Fig. 2).

Researchers identified an ONI SST-related statistical 3-MRM threshold of $\geq 0.5{ }^{\circ} \mathrm{C}$ for the likely onset of El 
Niño's anomalous SST warming that would remain above that certain threshold for several months. To qualify officially as an El Niño episode, the SST anomaly must continue at $\geq 0.5{ }^{\circ} \mathrm{C}$ or higher for a total of 5 consecutive 3 -month running means (3-MRMs) (NOAA 2019b). This period of time encompasses 7 consecutive months.

According to an anonymous reviewer of this article, "The choices of the criterion parameters for the ONI (threshold value of $0.5,5$ consecutive 3 -MRMs, etc.) were established by an ad-hoc advisory committee to NOAA several decades ago and were [to this reviewer's knowledge] never published in peer review." Peer review notwithstanding, the parameters for ONI are followed by various members of the El Niño research and forecast communities (WMO 2006). For example, the ONI is used operationally by National Meteorological and Hydrological Services (NMHSs) such as the Philippine Atmospheric, Geophysical and Astronomical Services Administration (PAGASA) and Ethiopia's National Meteorological Service, as well as NMHSs throughout the Caribbean and Central America region. The ONI is one of the various tools in several NMHSs' El Niño-related forecasting and warnings tool kits along with the Southern Oscillation

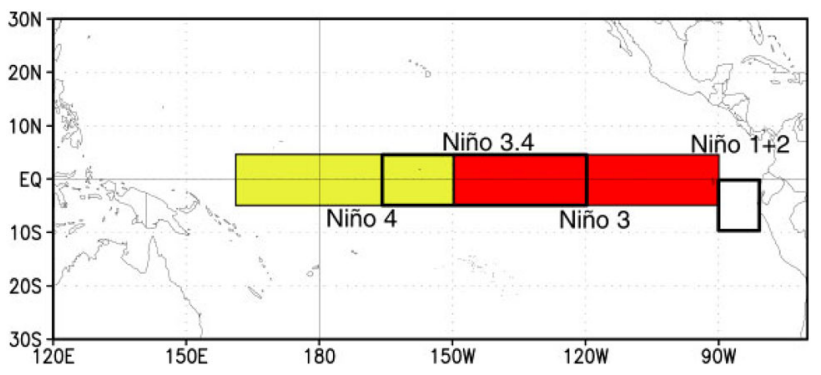

Fig. 2 Map of Niño regions across the tropical Pacific Ocean. Source: NOAA (2019a)

Index (SOI), Madden-Julian Oscillation (MJO), the Pacific Decadal Oscillation (PDO), the Indian Ocean Dipole (IOD), and the like (for example, Glantz et al. 2018). The reviewer noted that different regions around the globe known to be influenced by El Niño and its teleconnections have identified parameters they rely on for forecasts and warnings. For example, Peru focuses on tropical Pacific regions Niño 1 and 2; Japan on Niño 3; South Pacific countries favor the SOI. National Meteorological and Hydrological Services may also rely on various

\section{El Niño and Rainfall}

El Niño conditions in the tropical Pacific are known to shift rainfall patterns in many different parts of the world. Although they vary somewhat from one El Niño to the next, the strongest shifts remain fairly consistent in the regions and seasons shown on the map below.

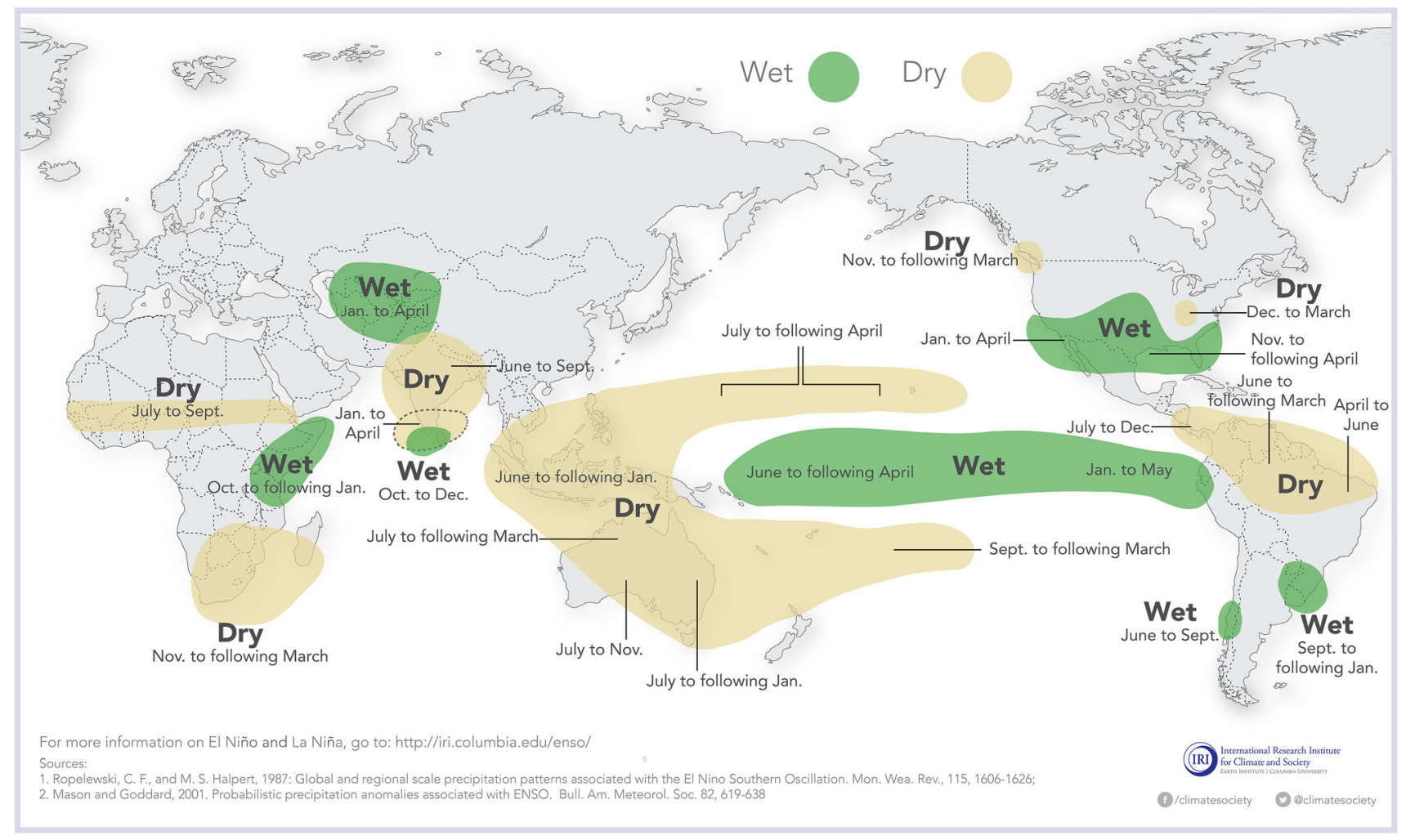

Fig. 1 Map of El Niño-related rainfall patterns in various locations around the globe. Source: IRI (n.d.) 
combinations of these parameters for their El Niño-related warning systems (for example, WMO 2006).

NOAA's Climate Prediction Center (CPC) website presents the following criteria for its ONI index values:

Warm [red, El Niño] and cold [blue, La Nina] periods based on a threshold of $\pm 0.5^{\circ} \mathrm{C}$ for the Oceanic Niño Index (ONI) [3-month running mean ... SST anomalies in the Niño 3.4 region $\left(5^{\circ} \mathrm{N}-5^{\circ} \mathrm{S}, 120^{\circ}-\right.$ $\left.170^{\circ} \mathrm{W}\right)$ ], based on centered 30 -year base periods updated every 5 years. For historical purposes, periods of below and above normal SSTs are colored in blue and red when the threshold is met for a minimum of 5 consecutive overlapping seasons. The ONI is one measure of the El Niño-Southern Oscillation [ENSO], and other indices can confirm whether features consistent with a coupled ocean-atmosphere phenomenon accompanied these periods (NOAA 2019b).

An El Niño episode is defined as an event from its onset to its end. A season is defined as a 3-MRM. Identifying an El Niño episode is not the same as forecasting emerging El Niño conditions. Though this distinction between an episode and conditions may be known to El Niño researchers, it may not be understood by societal users of El Niñorelated information. This distinction is at least as important to potential users of such information as it is to researchers and must be made explicit to users of the Oceanic Niño Index (ONI) who may see ONI monthly SST means as a forecast as opposed to a hindcast.

The Expert Team on El Niño and La Niña Definitions of the World Meteorological Organization's (WMO) Commission for Climatology noted in its Catalogue of Indices and Definitions of El Niño and La Niña in Operational Use by WMO Members that "Specifically, users include Member governments, their agencies and in particular their National Meteorological and Hydrological Services (NMHSs), media, emergency managers, climate scientists, weather forecasters, hydrologists, academia, water managers, and a broad array of decision makers at international, national, regional, and local levels" (WMO 2006).

Based on a consensus forecast, NOAA issues a Watch suggesting the potential for El Niño conditions to develop over the next several months (NOAA 2019c). The consensus forecast issued by scientists at both NOAA CPC and International Research Institute for Climate and Society (IRI 2018) combines observational data with predictive output generated by several computer models (see Fig. 3). It also incorporates expert judgment whereby forecasters provide different interpretations of the forecast before coming to an agreed upon consensus. The Watch, which could encompass several months of Watches, is followed by an Advisory, which at this point indicates an El Niño event is in-the-making, alerting potentially affected countries of El Niño's onset. The Advisory is informed by the observations of the coupling of SST changes (ONI value of $\geq 0.5^{\circ} \mathrm{C}$ ) with atmospheric changes (for example, weaker Walker Circulation) that signal sustained warming waters (IRI 2018; NOAA 2019c).

In the ENSO Blog, Becker (2015) noted that "The El Niño/Southern Oscillation (ENSO) is a coupled phenomenon, though, so we also monitor the atmosphere for signs that it is responding to those positive SST anomalies. For the last few months, we've been seeing some suggestions of borderline atmospheric El Niño conditions, but until this month [March] we were below that borderline. This month, we've finally crept above it, and thus NOAA is declaring the onset of El Niño conditions."

For the 2018-2019 El Niño, U.S. media (Berardelli 2019) reported the following: "It's official, an El Niño advisory is now in effect for the globe. After several months under a 'watch,' teetering on the edge of El Niño, NOAA's CPC has finally pulled the trigger. But CPC determined ... those criteria are met based on the presence of above-average sea surface temperatures across most of the equatorial Pacific Ocean and corresponding changes in the overlying atmospheric circulation."

The following schematic diagram (Fig. 4) provides an overview of the CPC decision-making process for monitoring changes in Pacific SSTs for the purpose of issuing an El Niño Advisory.

Ideally, the ONI-based onset forecast provides decision makers in governments, corporations, and civil society with quantitative information in the form of monthly online discussions and "actionable" advisories. This warning enables them to prepare for foreseeable (that is, historically known) adverse consequences (for example, droughts, floods, forest and bush fires, food insecurity, infectious disease outbreaks, and the like). Advisories catalyze tactical societal disaster risk and harm reduction efforts. The problem with the Advisory, however, is that it likely comes when teleconnected societal impacts, which can take some weeks to be detected, have likely begun to appear in $\mathrm{El}$ Niño-affected societies. In retrospect, the El Niño onset may be declared after an event is already happening. For example, during the two most recent El Niño events, the advisories were issued when El Niño was already in progress, by a few months (see Table 1).

In this article, we explore the detection of an El Niño's locked-in marker and present new insights about the ONI and advisories through a review of the ONI record. By identifying a locked-in "marker," we are referring to a tipping point in the midst of an El Niño process after which it must continue to run its course for several months before the naturally occurring episode ends. We propose that the first appearance of the $\geq 0.7{ }^{\circ} \mathrm{C}$ ONI 3-MRM can provide 


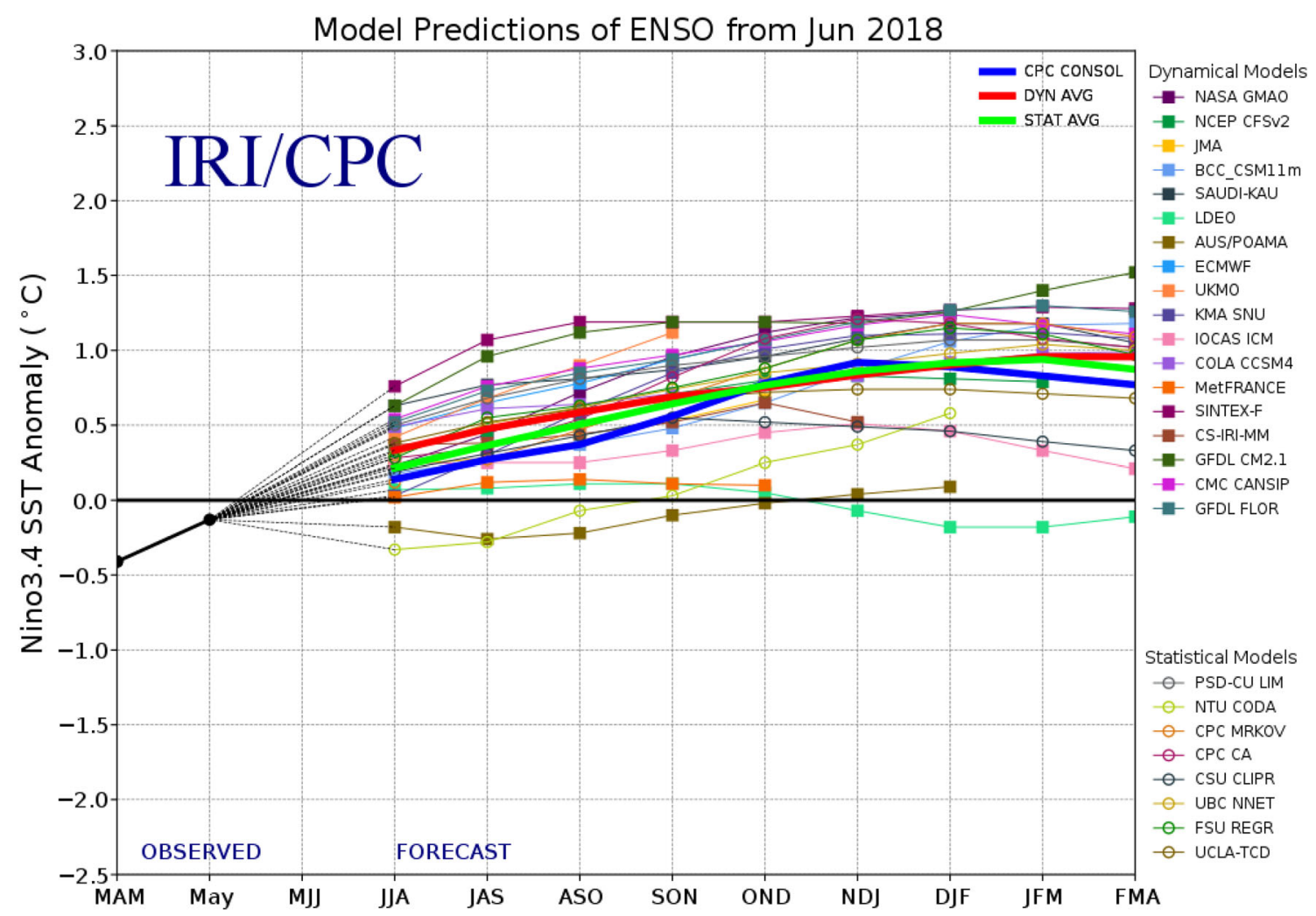

Fig. 3 Example of multiple model predictions and probability forecast of ENSO, June 2018. MAM March-April-May, and so forth. Source: IRI (2018)

Fig. 4 Schematic by Glenn Becker in 2015, as shown on the ENSO Blog. Source: Becker (2015)

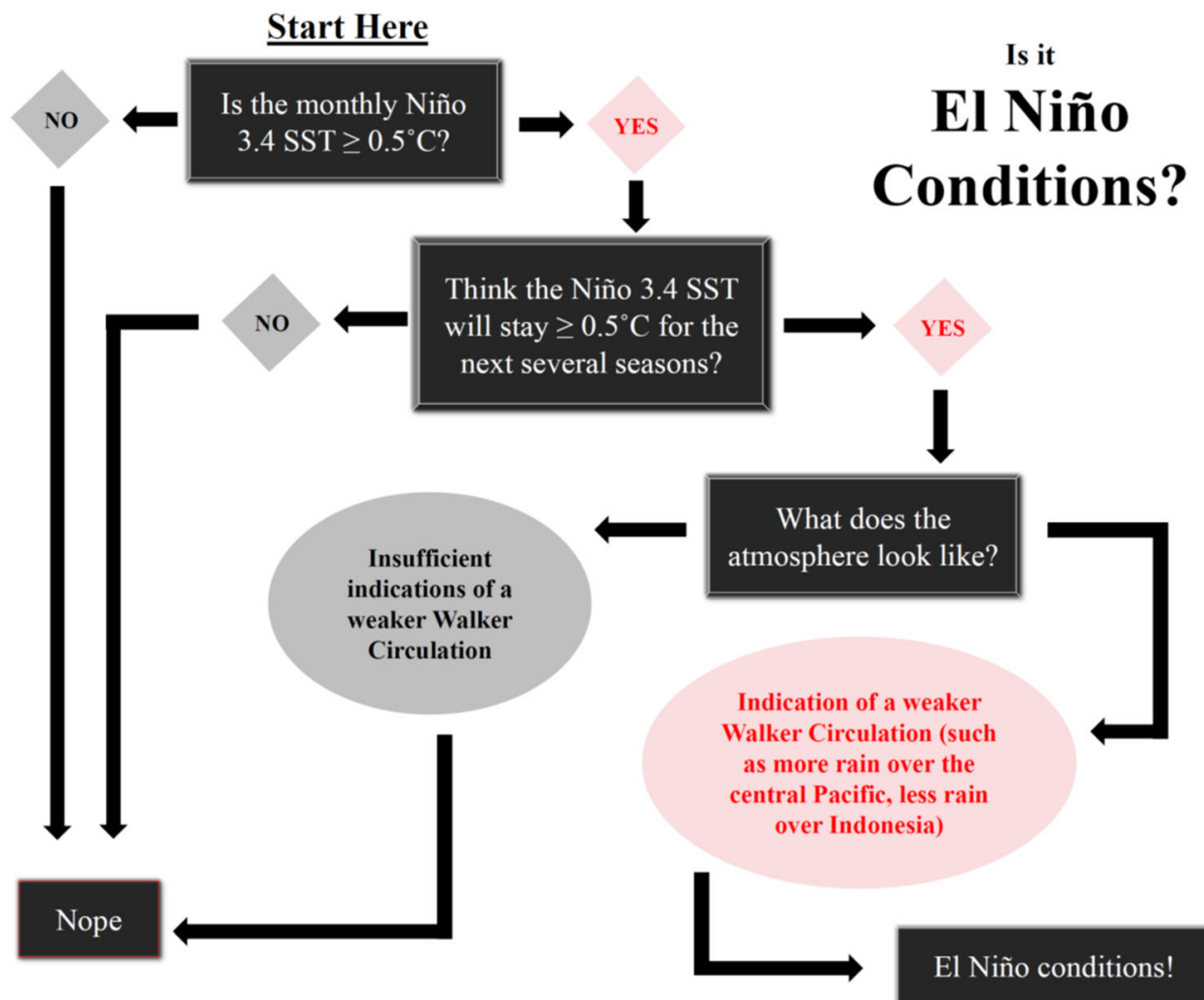


Table 1 Comparison of dates of El Niño Watch, first ONI Index value, El Niño Advisory, and months since first ONI 3-MRM value $\geq 0.5{ }^{\circ} \mathrm{C}$. Sources: NOAA (2019b, d)

\begin{tabular}{lllll}
\hline El Niño event & Watch date & First $\geq 0.5{ }^{\circ} \mathrm{C}$ or above, season (3-MRM) & Advisory date (onset) & $\#$ of months since $\geq 0.5{ }^{\circ} \mathrm{C}$ \\
\hline 2018-2019 & 14 Jun. 2018 & 0.7, Sept., Oct., Nov. 2018 & 14 Feb. 2019 & 3 months \\
2014-2016 & 6 Mar. 2014 & 0.6, Oct., Nov., Dec. 2014 & 5 Mar. 2015 & 3 months \\
2009-2010 & 4 Jun. 2009 & 0.5, Jun., Jul., Aug. 2009 & 9 Jul. 2009 & 0 months \\
\hline
\end{tabular}

some months of reliable lead time for societal decision makers to continue to "get ready" by preparing for $\mathrm{El}$ Niño's associated impacts many of which in fact continue well after an episode has ended. Such a marker could strengthen for users both the reliability of NOAA's ONIbased advisory as well as the confidence of its early warning process.

Whereas the ONI is a measure of SSTs in the Niño 3.4 region, outgoing longwave radiation (OLR) measurements monitor atmospheric processes in the tropical Pacific. Chiodi and Harrison (2016) have written, "OLR observations provide information about the development of deep atmospheric convection activity in the tropics. Changes in tropical convection patterns, along with the associated atmospheric heating anomalies, are believed to dynamically link the anomaly state of the tropical Pacific with its evident influence on weather conditions elsewhere." They also noted that "Over the time for which satellite-based OLR information has been available (since 1974), most of the useful El Niño associations have been contributed primarily by the subset of El Niño years that are identifiable by their signature in tropical Pacific OLR .... The OLR El Niño index identifies 1982-1983, 1986-1987, 1991-1992, and 1997-1998 as 'OLR El Niño' years” (see Table 2). For each of the years they consider to be "OLR El Niño years," the $\geq 0.7{ }^{\circ} \mathrm{C}$ ONI 3-MRM as the first marker of the locked-in phase is consistent with their OLR El Niño Index for major events.

\section{Might There Be an El Niño "Locked-in" Marker?}

The current ONI-based monitoring system, using the first $\geq 0.5{ }^{\circ} \mathrm{C} 3-\mathrm{MRM}$ as the indicator of a likely El Niño's onset, seems to work well for the forecasters, providing continuous early warnings that follow the first appearance of a $\geq 0.5{ }^{\circ} \mathrm{C}$ or higher 3 -MRM. They inform a society to prepare their responses to hydrometeorological threats. Yet, with the passing of each month in El Niño's life cycle, the societal and environmental risks and harms from El Niño's impacts have ratcheted upward. The earlier the public believes it is receiving reliable warnings, the earlier it is likely to pursue tactical preparations.

We are aware of a dataset that goes back to 1860 but reliability of the data becomes increasingly reduced. The compiler of that time series, Eric Webb (2019), provided the following cautionary note when using his ENS ONI (ensemble ONI): "The ENS ONI attempts to provide as long and reliable of an instrumentally-based ENSO record as possible while maintaining simplicity in its construction and being available for real-time scrutiny. While the quality and quantity of data platforms and spatiotemporal coverage is relatively less reliable, less numerous, and more sparse respectively, the number of ENSO event samples under the ENS ONI is more than double the "reliable' record (1950-present)."

If a locked-in marker were to exist, it could foster confidence in governments to prepare sooner for impacts on their societies and the ecosystems on which they depend. In our review of the ONI time series we identified the $\geq 0.7{ }^{\circ} \mathrm{C} 3-\mathrm{MRM}$ as that "tipping point" indicator of

Table 2 Outgoing longwave radiation (OLR) El Niño Index and Oceanic Niño Index (ONI) 3-month running mean (3-MRM) anomalous sea surface temperature (SST) warming in Niño 3.4. Sources: Chiodi and Harrison (2016), NOAA (2019b)

\begin{tabular}{lll}
\hline OLR El Niño index subset & 3-month running mean (MRM) & ONI $\left(1\right.$ st 3 -MRM $\left.\geq 0.5^{\circ} \mathrm{C}\right)$ \\
\hline $1982-1983$ & Jun., Jul., Aug. & $0.8^{\circ} \mathrm{C}$ \\
$1986-1987$ & Aug., Sept., Oct. & $0.7^{\circ} \mathrm{C}$ \\
$1991-1992$ & Jun., Jul., Aug. & $0.7^{\circ} \mathrm{C}$ \\
$1997-1998$ & Jun., Jul., Aug. & $1.5^{\circ} \mathrm{C}$ \\
\hline
\end{tabular}


El Niño's "locked-in" marker, after which the El Niño process must run its course. Such information can provide additional confidence and lead time for decision makers in the ONI-related warnings that are associated with the first appearance of $\mathrm{a} \geq 0.5^{\circ} \mathrm{C} 3-\mathrm{MRM}$ and an observed atmospheric response.

We evaluated the ONI time series of monthly as well as 3-month running means from 1950 to 2020, focusing on the prolonged anomalous SST departures from average for $\geq 0.5^{\circ} \mathrm{C}$. The process was as follows: each instance where the 3-MRM threshold value of $0.5{ }^{\circ} \mathrm{C}$ appeared for a first time, we noted if a total of 4 consecutive 3-MRM values of $\geq 0.5{ }^{\circ} \mathrm{C}$ followed. Similarly, we applied this method to the 3 -MRM threshold values of $0.6{ }^{\circ} \mathrm{C}$ and $\geq 0.7{ }^{\circ} \mathrm{C}$ when they first appeared in the time series. An ONI early warning was considered a false start, if the initial 3-MRM threshold value of $\geq 0.5^{\circ} \mathrm{C}$ was not followed by 4 additional 3-MRMs of $\geq 0.5{ }^{\circ} \mathrm{C}$.

The success rates for each of those index values were evaluated for forecasting an El Niño event's onset and for identifying its locked-in phase. Although the $\geq 0.5^{\circ} \mathrm{C}$ index value was observed most (11 events), there were two false starts in 1980 and 1993 . Using the $\geq 0.6{ }^{\circ} \mathrm{C}$ threshold, six events began with this index value with one false start observed in 1968. Similarly, the $\geq 0.7{ }^{\circ} \mathrm{C}$ value was identified as the onset in 6 events, but there were no false starts associated with this threshold, meaning El Niño conditions were sustained thereafter. On two occasions (1958-1959 and 1993), respectively, the ONI 3-MRM values of $\geq 0.5^{\circ} \mathrm{C}$ did not exceed the $0.6{ }^{\circ} \mathrm{C}$ value. In the instance of 1993, it is a curious case in which the $\geq 0.7^{\circ} \mathrm{C}$ value was observed but an El Niño episode (by ONI criteria) did not occur. There is a question about whether 1993 was in fact an El Niño year by other criteria or indices (see Sect. 2.1).

\subsection{Curious Case of 1993}

Today's ONI record does not include 1993 as an El Niño episode. Yet, in 1993 it was considered an El Niño by senior researchers (for example, McPhaden 1990; Kessler and McPhaden 1995; Goddard and Graham 1996; Trenberth and Hoar 1996). Even today, there are several references on various NOAA webpages, referring to 1993. Some countries such as Peru and Australia also report 1993 as a weak El Niño event, by their criteria (for example, see Peru's Institute for Geophysics (ENFEN 2012); Australia's Bureau of Meteorology (BOM, Australian Government n.d.)). The Southern Oscillation Index, according to Australia's BOM, showed a significant deviation representative of a warm event in 1993.

The ONI shows 1993 as a near-El Niño, exhibiting the following values (FMA $\left(0.5^{\circ} \mathrm{C}\right)$, MAM $\left(0.7^{\circ} \mathrm{C}\right)$, AMJ $\left(0.7^{\circ} \mathrm{C}\right)$, and $\left.\mathrm{MJJ}\left(0.6^{\circ} \mathrm{C}\right)\right)$ as shown in Table 3. This series fell short of being an El Niño episode, by one more 3-MRM at the $\geq 0.5^{\circ} \mathrm{C}$ level even though it exhibited El Niño conditions. As an "almost El Niño," this event's teleconnections likely spawned hazardous teleconnections.

Table 4 presents ONI values for the 1997-1998 "El Niño of the Century," as an example. As one can see, the

Table 3 Oceanic Niño Index (ONI) values for 1991 to 1994 (Bold type numbers depicts an El Niño episode and the italicized bold numbers suggests that 1993 was a near-El Niño event). JJA June-July-August, and so forth. Source: Adapted from GGWeather (2019)

\begin{tabular}{lllllllllrrrrr}
\hline Year & DJF & JFM & FMA & MAM & AMJ & MJJ & JJA & JAS & ASO & SON & OND & NDJ \\
\hline 1991 & 0.4 & 0.3 & 0.2 & 0.3 & $\mathbf{0 . 5}$ & $\mathbf{0 . 6}$ & $\mathbf{0 . 7}$ & $\mathbf{0 . 6}$ & $\mathbf{0 . 6}$ & $\mathbf{0 . 8}$ & $\mathbf{1 . 2}$ \\
1992 & $\mathbf{1 . 7}$ & $\mathbf{1 . 6}$ & $\mathbf{1 . 5}$ & $\mathbf{1 . 3}$ & $\mathbf{1 . 1}$ & $\mathbf{0 . 7}$ & 0.4 & 0.1 & -0.1 & -0.2 & -0.3 & -0.1 \\
1993 & 0.1 & 0.3 & $\mathbf{0 . 5}$ & $\mathbf{0 . 7}$ & $\mathbf{0 . 7}$ & $\mathbf{0 . 6}$ & 0.3 & 0.3 & 0.2 & 0.1 & 0 \\
1994 & 0.1 & 0.1 & 0.2 & 0.3 & 0.4 & 0.4 & 0.4 & 0.4 & $\mathbf{0 . 6}$ & 0.7 & $\mathbf{1}$ & $\mathbf{1 . 1}$ \\
\hline
\end{tabular}

Bold numbers indicate the locked in phase of El Niño based the ONI value of $\geq 0.5^{\circ} \mathrm{C}$

Table 4 Oceanic Niño Index (ONI) values for 1996 to 1998 (Bold numbers = El Niño event). DJF December-January-February, and so forth. A "season" a 3-month running mean. An episode 5 consecutive 3 -MRMs at $\geq 0.5{ }^{\circ} \mathrm{C}$ and above. Source: NOAA (2019b)

\begin{tabular}{rrrrrrrrrrrrr}
\hline Year & DJF & JFM & FMA & MAM & AMJ & MJJ & JJA & JAS & ASO & SON & OND & NDJ \\
\hline 1996 & -1 & -0.8 & -0.6 & -0.4 & -0.3 & -0.3 & -0.3 & -0.3 & -0.4 & -0.4 & -0.4 & -0.5 \\
1997 & -0.5 & -0.4 & -0.1 & 0.3 & $\mathbf{0 . 8}$ & $\mathbf{1 . 2}$ & $\mathbf{1 . 6}$ & $\mathbf{1 . 9}$ & $\mathbf{2 . 1}$ & $\mathbf{2 . 3}$ & $\mathbf{2 . 4}$ & $\mathbf{2 . 4}$ \\
1998 & $\mathbf{2 . 2}$ & $\mathbf{1 . 9}$ & $\mathbf{1 . 4}$ & $\mathbf{1}$ & $\mathbf{0 . 5}$ & -0.1 & -1 & -1 & -1.3 & -1.4 & -1.5 & -1.6 \\
\hline
\end{tabular}

Bold numbers indicate the locked in phase of El Niño based the ONI value of $\geq 0.5^{\circ} \mathrm{C}$ 
Table 5 Oceanic Niño Index (ONI) values for 2018 to 2019 (Bold numbers = El Niño event). DJF December-January-February, and so forth. $A$ "season" a 3-month running mean. An episode 5 consecutive 3-MRMs at $\geq 0.5{ }^{\circ} \mathrm{C}$ and above. Source: NOAA (2019b)

\begin{tabular}{lcrrrrrrrrrrr}
\hline Year & DJF & \multicolumn{1}{c}{ JFM } & \multicolumn{1}{c}{ FMA } & MAM & \multicolumn{1}{c}{ AMJ } & MJJ & JJA & JAS & ASO & SON & OND & NDJ \\
\hline 2018 & -1 & -0.8 & -0.6 & -0.4 & -0.1 & 0.1 & 0.1 & 0.2 & 0.4 & $\mathbf{0 . 7}$ & $\mathbf{0 . 9}$ & $\mathbf{0 . 8}$ \\
2019 & $\mathbf{0 . 8}$ & $\mathbf{0 . 8}$ & $\mathbf{0 . 8}$ & $\mathbf{0 . 8}$ & $\mathbf{0 . 6}$ & $\mathbf{0 . 5}$ & 0.3 & 0.1 & 0.1 & 0.3 & \\
\hline
\end{tabular}

Bold numbers indicate the locked in phase of El Niño based the ONI value of $\geq 0.5^{\circ} \mathrm{C}$

1997 April, May, June (AMJ) $0.8^{\circ} \mathrm{C}$ (3-MRM) value depicted the El Niño's onset and its locked-in marker at the same time. El Niño was sure to run its course of several months before the SST anomaly and ONI indicators would return to ENSO neutral. In the absence of awareness of a locked-in phase (see, for example, Barnston et al. (1999) on the controversy over the forecasting of the onset of this El Niño event), users would wait for some months before being assured (by the issuing of an Advisory) that an El Niño had met the additional 3-MRMs criterion and that there was an atmospheric response to the warmer SSTs in Niño 3.4.

In the case of the most recent El Niño (2018-2019), the NOAA Advisory was issued by mid-February 2019, which followed several months after having observed a $+0.7{ }^{\circ} \mathrm{C}$ 3-MRM in October 2018 (see Table 5).

\section{Discussion}

Regardless of the length of an El Niño's life cycle, El Niño's adverse consequences for societies, environments, and ecosystems often start as SSTs increase toward a warm ENSO anomaly, though still in a neutral phase, and can continue well after the event has dissipated.

The important difference between the first appearance of $\mathrm{a} \geq 0.5{ }^{\circ} \mathrm{C}$ and of $\mathrm{a} \geq 0.7^{\circ} \mathrm{C} 3-\mathrm{MRM}$ value relates to issuing an additional official advisory that the El Niño process has become locked-in. Once an El Niño has "locked in," as it apparently does with an ONI threshold value of $\geq 0.7^{\circ} \mathrm{C}$, it will not collapse for a few of months at the least. As noted earlier, once a value of $\geq 0.5^{\circ} \mathrm{C}$ first appears in the 3-MRMs, users must wait to see if similar consecutive 3-MRMs will follow along with the Advisory, which indicates that atmospheric changes associated with an El Niño are also observed. The initial $\geq 0.5{ }^{\circ} \mathrm{C}$ departure level at the least sparks awareness, but a higher initial ONI index value of $\geq 0.7^{\circ} \mathrm{C}$ can serve as a reliable and credible marker of the sustained locked-in El Niño phase.

With a $\geq 0.7{ }^{\circ} \mathrm{C}$ initial anomaly marker, the reliability that a sustained El Niño would continue was $100 \%$. In 21 out of 21 events, when the ONI 3-MRM value of $\geq 0.7{ }^{\circ} \mathrm{C}$ was initially reached, El Niño continued to develop for the next several 3 -MRMs. Compared to the $\geq 0.5{ }^{\circ} \mathrm{C}$ threshold, the $\geq 0.7{ }^{\circ} \mathrm{C}$ value can provide greater confidence to users of El Niño warnings that they need to continue to take mitigative if not preventive action.

It is important to note that the ONI values are recalibrated every 5 years (due to the global warming signal), beginning in 2013 (Lindsey 2013). As a result, the recalibration can move events on or off the official list of episodes and can shift its level of intensity from stronger to weaker, or vice versa. Some El Niño episodes are shown to have been longer than were originally considered at the time of their occurrences. For example, Table 6 shows a comparison of ONI in 2008 (before a global warming recalibration) with ONI in 2019 (after a global warming recalibration). It shows that the 1957-1958 event changed

Table 6 Oceanic Niño Index (ONI) data values in 2008 and 2019, comparing 1957 to 1959 (Bold numbers = El Niño event). DJF DecemberJanuary-February, and so forth. Source: NOAA (2010, 2019b)

\begin{tabular}{|c|c|c|c|c|c|c|c|c|c|c|c|c|}
\hline Year & DJF & JFM & FMA & MAM & AMJ & MJJ & JJA & JAS & ASO & SON & OND & NDJ \\
\hline \multicolumn{13}{|c|}{ ONI 2008} \\
\hline 1957 & -0.5 & -0.1 & 0.3 & 0.6 & 0.7 & 0.9 & 0.9 & 0.9 & 0.9 & 1 & 1.2 & 1.5 \\
\hline 1958 & 1.7 & 1.5 & 1.2 & 0.8 & 0.6 & 0.5 & 0.3 & 0.1 & 0 & 0 & 0.2 & 0.4 \\
\hline 1959 & 0.4 & 0.5 & 0.4 & 0.2 & 0 & -0.2 & -0 & -1 & -0.4 & -0.3 & -0.2 & -0.2 \\
\hline \multicolumn{13}{|c|}{ ONI 2019} \\
\hline 1957 & -0.2 & 0.1 & 0.4 & 0.7 & 0.9 & 1.1 & 1.3 & 1.3 & 1.3 & 1.4 & 1.5 & 1.7 \\
\hline 1958 & 1.8 & 1.7 & 1.3 & 0.9 & 0.7 & 0.6 & 0.6 & 0.4 & 0.4 & 0.4 & 0.5 & 0.6 \\
\hline 1959 & 0.6 & 0.6 & 0.5 & 0.3 & 0.2 & -0.1 & -0.2 & -0.3 & -0.1 & 0 & 0 & 0 \\
\hline
\end{tabular}




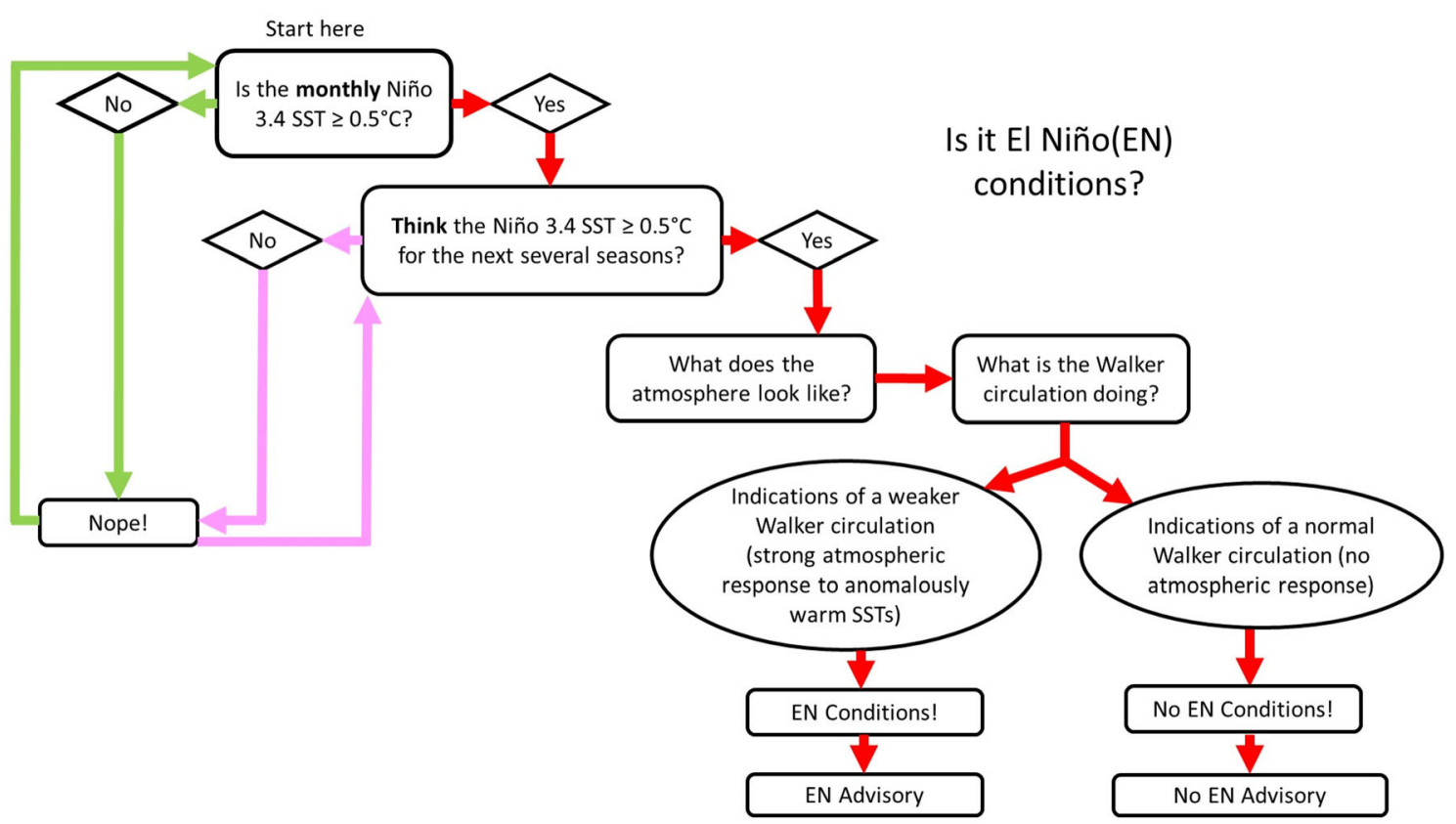

Fig. 5 Becker's 2015 schematic from the ENSO Blog modified by the authors to provide more detail on decision making. Green and pink lines represent feedback loops, while red is the forecasting pathway in the decision tree

in intensity and increased by one season, for example, by one 3-MRM. Moreover, after that recalibration an additional El Niño event emerged in late 1958 to early 1959 and a La Niña event was removed in 1959.

\section{Summary Comments}

Our research reviewed NOAA's Oceanic Niño Index $(\mathrm{ONI})$, which is used to record for historical purposes the occurrence and duration of El Niño episodes, based on the monitoring of sea surface temperatures (SSTs) in the central Pacific's Niño 3.4 region. The ONI is used to identify an above average anomalous SST threshold that persists for several months, encompassing the first indication of the onset and the end of an El Niño episode. The first appearance of $\geq 0.5^{\circ} \mathrm{C}$ 3-MRM suggests with a high probability that an El Niño could emerge once atmospheric response to the warming SSTs is also observed: this is when an advisory is issued. Using together the $\geq 0.5^{\circ} \mathrm{C}$ monthly value and 3 -MRM and $\geq 0.7{ }^{\circ} \mathrm{C} 3$-MRM marker assures that at-risk populations are reliably being warned as soon as possible about a sustained anomalous warming of SSTs in Niño 3.4.

For additional stronger advisories following the initial appearance of $\geq 0.5^{\circ} \mathrm{C} 3$-MRM, one must wait several months for additional 3-MRMs to be calculated until the atmosphere responds to the warmer SSTs. Our findings show that the first appearance of ONI's 3-MRM of $\geq 0.7{ }^{\circ} \mathrm{C}$ could serve as an earliest reliable and credible indicator-as-marker of El Niño's emerging locked-in phase. This tipping point is the first sign that a sustained anomalous SST warming in the Niño 3.4 region is assured to continue. In the ONI record from 1950 to 2020, no El Niño collapsed prematurely, using the first appearance of the $\geq 0.7{ }^{\circ} \mathrm{C} 3$-MRM as a tipping point. The $\geq 0.7{ }^{\circ} \mathrm{C}$ marker can provide additional reliability to the $\geq 0.5{ }^{\circ} \mathrm{C}$ onset value for at-risk societies to get ready for El Niño's foreseeable societal and ecological impacts.

The identification and, therefore, forecast of an El Niño $0.7{ }^{\circ} \mathrm{C}$ locked-in marker is important to NMHSs, governments, and communities in teleconnected places, even though it does not provide information about its peak intensity or duration. Forecasting the adverse societal and ecological consequences of ENSO's extremes requires a different set of research foci and tools, as they are influenced by a number of factors such as the regional oscillations in the air and sea (for example, Indian Ocean Dipole) that can affect not only El Niño, but its foreseeable impacts as well. While the ONI $\geq 0.5^{\circ} \mathrm{C} 3$-MRM provides an awareness-raising reliable "heads up" warning to societies to consider preparing for foreseeable societal impacts, the initial $\geq 0.7{ }^{\circ} \mathrm{C} 3$-MRM provides a higher level of confidence for undertaking actions needed in the face of El Niño's climate, water, and weather related impacts.

As a final comment, in this research it became clear that the schematic from the ENSO Blog (Fig. 4) does not 
provide enough accuracy or details for users that would better describe the El Niño monitoring and forecast process. Thus, we took the liberty, as users of the ONI, to modify the diagram to better explain to other users the decision-making processes involved (Fig. 5).

Acknowledgements The authors greatly appreciate the comments to various drafts of this article: Robert J. Ross, Lino Naranjo, Anthony Lucero and the various official and other reviewers of this paper. Their comments and critiques were very instructive. This study was made possible through the support provided by the Office of U.S. Foreign Disaster Assistance, Bureau for Democracy, Conflict and Humanitarian Assistance, U.S. Agency for International Development. The opinions expressed in this publication are those of the authors and do not necessarily reflect views of the U.S. Agency for International Development or NOAA.

Open Access This article is licensed under a Creative Commons Attribution 4.0 International License, which permits use, sharing, adaptation, distribution and reproduction in any medium or format, as long as you give appropriate credit to the original author(s) and the source, provide a link to the Creative Commons licence, and indicate if changes were made. The images or other third party material in this article are included in the article's Creative Commons licence, unless indicated otherwise in a credit line to the material. If material is not included in the article's Creative Commons licence and your intended use is not permitted by statutory regulation or exceeds the permitted use, you will need to obtain permission directly from the copyright holder. To view a copy of this licence, visit http://creativecommons. org/licenses/by/4.0/.

\section{References}

Barnston, A.G., M.H. Glantz, and Y. He. 1999. Predictive skill of statistical and dynamical climate models in SST forecasts during the 1997-98 El Niño episode and the 1998 La Niña onset. Bulletin of the American Meteorological Society 80(2): 218-243.

Becker, E. 2015. March 2015 ENSO discussion: El Niño is here. ENSO Blog, 5 March 2015. https://www.climate.gov/newsfeatures/blogs/enso/march-2015-enso-discussion-el-ni\%C3\% B1o-here. Accessed 29 Nov 2019.

Berardelli, J. 2019. The El Nino has arrived: What does it mean for the weather? CBS News, 14 February 2019. https://www. cbsnews.com/news/el-nino-2019-weather-forecast-what-is-elnino/. Accessed 1 Dec 2019.

BOM (Bureau of Meteorology), Australian Government. n.d. Southern Oscillation Index-1993-2000. http://www.bom.gov.au/cli mate/current/soi-1993-2000.shtml. Accessed 25 Sept 2019.

Caviedes, C.N. 1984. El Niño 1982-83. Geographical Review 74(3): 267-290.

Chiodi, A.M., and D.E. Harrison. 2016. 2015-16 El Nino seasonal weather impacts from the OLR event perspective. Presented at the 41st NOAA Annual climate diagnostics and prediction workshop, 3-6 October 2016, Orono, Maine, USA. https://www. nws.noaa.gov/ost/climate/STIP/41CDPW/41cdpw-AChiodi.pdf. Accessed 13 Jan 2020.

ENFEN (Peru's Technical Committee that studies El Niño (Comité Técnico del Estudio Nacional del Fenómeno El Niño)). 2012. Operational definition of El Niño and La Niña events and its magnitudes on the Peru coast (Definición operacional de los eventos El Niño y La Niña y sus magnitudes en la costa del Perú). http://www.imarpe.pe/imarpe/archivos/informes/imarpe comenf_not_tecni_enfen_09abr12.pdf. Accessed 15 Nov 2018.
GGWeather (Golden Gate Weather Services). 2019. El Niño and La Niña years and intensities: Based on the ONI. https://ggweather. com/enso/oni.htm. Accessed 25 Sept 2019.

Glantz, M.H. (ed.). 2001. Once burned, twice shy? Lessons learned from the 1997-98 El Niño. Tokyo: United Nations University. https://collections.unu.edu/view/UNU:2374. Accessed 13 Jan 2020.

Glantz, M.H., L. Naranjo, M.A. Baudoin, and I.J. Ramírez. 2018. What does it mean to be El Niño ready? Atmosphere 9(3): Article 94.

Goddard, L., and N.E. Graham. 1996. El Niño in the 1990s. Journal of Geophysical Research 102: 10423-10436.

IRI (International Research Institute for Climate and Society). n.d. El Niño and rainfall map. https://iridl.ldeo.columbia.edu/maproom/ IFRC/FIC/EINinoandRainfall.png. Accessed 12 Feb 2012.

IRI (International Research Institute for Climate and Society). 2018. ENSO forecast: 2018 June quick outlook. https://iri.columbia. edu/our-expertise/climate/forecasts/enso/current/?enso_tab= enso-cpc_plume. Accessed 1 Dec 2019.

Kessler, W.S., and M.J. McPhaden. 1995. Oceanic equatorial waves and the 1991-93 E1 Niño. Journal of Climate 8: 1757-1774.

Lindsey, R. 2013. In watching for El Niño and La Niña, NOAA adapts to global warming. https://www.climate.gov/news-fea tures/understanding-climate/watching-el-ni\%C3\%B1o-and-lani\%C3\%B1a-noaa-adapts-global-warming. Accessed 1 Jul 2019.

McGregor, G.R., and K. Ebi. 2018. El Niño Southern Oscillation (ENSO) and health: An overview for climate and health researchers. Atmosphere 9(7): Article 282.

McPhaden, M.J. 1990. TOGA-TAO and the 1991-93 El NiñoSouthern Oscillation event. NOAA. https://www.pmel.noaa.gov/ pubs/docs/mcph1401.html. Accessed 1 May 2019.

McPhaden, M.J., S.E. Zebiak, and M.H. Glantz. 2006. ENSO as an integrating concept in earth science. Science 314(5806): $1740-1745$.

NOAA (National Oceanic and Atmospheric Administration). 2010. Cold and warm episodes by season. Spreadsheet previously available online at http://www.cpc.ncep.noaa.gov/products/ana lysis_monitoring/ensostuff/ensoyears.shtml. Accessed Aug 2010.

NOAA (National Oceanic and Atmospheric Administration). 2019a. Nino regions. https://www.cpc.ncep.noaa.gov/products/analysis_ monitoring/ensostuff/nino_regions.shtml. Accessed 23 Dec 2019.

NOAA (National Oceanic and Atmospheric Administration). 2019b. Cold and warm episodes by season. https://origin.cpc.ncep.noaa. gov/products/analysis_monitoring/ensostuff/ONI_v5.php. Accessed 30 Apr 2020.

NOAA (National Oceanic and Atmospheric Administration). 2019c. ENSO alert system. https://www.cpc.ncep.noaa.gov/products/ analysis_monitoring/enso_advisory/enso-alert-readme.shtml. Accessed 29 Nov 2019.

NOAA (National Oceanic and Atmospheric Administration). 2019d. ENSO diagnostic discussion archive. https://www.cpc.ncep. noaa.gov/products/expert_assessment/ENSO_DD_archive.php. Accessed 1 Dec 2019.

Ramírez, I.J., S.C. Grady, and M.H. Glantz. 2013. Reexamining El Niño and cholera in Peru: A climate affairs approach. Weather, Climate, and Society 5(2): 148-161.

Ropelewski, C.F., and M.S. Halpert. 1987. Global and regional scale precipitation patterns associated with the El Niño Southern Oscillation. Monthly Weather Review 115: 1606-1626.

Trenberth, K., and T. Hoar. 1996. The 1990-1995 E1 Niño-Southern Oscillation event: Longest on record. Geophysical Research Letters 23(1): 57-60. 
Ubilava, D., and M. Abdolrahimi. 2019. The El Niño impact on maize yields is amplified in lower income teleconnected countries. Environmental Research Letters 14: Article 054008.

Webb, E. 2019. Ensemble Oceanic Niño Index (ENS ONI). https:// www.webberweather.com/ensemble-oceanic-nino-index.html. Accessed 15 Nov 2019.

WMO (World Meteorological Organization). 2006. Catalogue of indices and definitions of El Niño and La Niña in operational use by WMO members. Geneva: WMO Commission for Climatology. http://www.wmo.int/pages/prog/wcp/wcasp/documents/ ENSO-Indices-Catalogue_12062006.pdf. Accessed 13 Jan 2020.

Zebiak, S.E., B. Orlove, A.G. Munoz, C. Vaughan, J. Hansen, T. Troy, M.C. Thomson, A. Lustig, et al. 2015. Investigating El Niño-Southern Oscillation and society relationships. WIREs Climate Change 6(1): 17-34. 